\title{
Transportation System Development and Challenge in Jakarta Metropolitan Area, Indonesia

\author{
Muhammad Farda ${ }^{1,2} *$, Harun al-Rasyid Lubis ${ }^{1,2}$ \\ ${ }^{1}$ Transport Engineering Research Group, Faculty of Civil and Environmental Engineering, Institut Teknologi \\ Bandung, Jl. Ganesha 10, Bandung, 40132 \\ ${ }^{2}$ National Center for Sustainable Transportation Technology, Indonesia \\ *Email: muhammadfarda91@gmail.com
}

\begin{abstract}
Jakarta Metropolitan Area has been facing problem in terms of congestion and its chain effect, namely time value loss, high fuel consumption, and high greenhouse gas emission. The problem is caused by many factors, namely high population, high use of the private vehicle, inadequate current public transport supply, urban sprawling, etc. The government, both City and National Government has been formulating and implementing a plan to develop sustainable transportation that serves the citizen of Jakarta Metropolitan Area. This included the operation of Jakarta Bus Rapid Transit, KRL Commuter Line and Jakarta Mass Rapid Transit. In the near future, both inner city and metropolitan light rapid transit will also operate in this area. This paper reviews the development and challenge of the transportation system in Jakarta Metropolitan Area and proposes a recommendation to optimize the current transport system. In general, there are three components that should be considered to achieve sustainable transportation. Those components are i) strong transport authority, ii) integrated master plan, iii) Sustainable Resources, Funding, and Financing.
\end{abstract}

\section{Keywords}

Jakarta metropolitan area; Traffic congestion; Public transport

\section{Introduction}

Big cities today around the world are facing problems in terms of traffic congestion, high fuel consumption, and greenhouse gas emission. Ever since the beginning of mass car ownership era in the 1960s, road transportation has been the main consumer of fossil fuel and also the main contributor of greenhouse gas emission, especially in big cities [1]. The case is strengthened by [2] which stated that the global energy demand from the transportation sector has been increasing since 1970. This is due to the fact that congestion has been occurring in big cities around the world.

In more detail, the transport mode which is the biggest energy consumer is the private passenger vehicle, namely at $46.1 \%$ followed by freight vehicle at $25 \%$ [2]. This results in high greenhouse gas emission by the transport sector. Approximately $23 \%$ of worldwide greenhouse gas emission is generated by the transport sector [3]. This poses a significant risk to human health by causing lung disease, the risk of premature death and eye irritation [1]. Such risk also threatens the segment of society who are most vulnerable.

Moreover, an individual and a city's economy is also impacted, in a negative way, by traffic congestion. Time is spent unproductively on the road, which leads to higher operational cost, higher road maintenance cost and also driver/passenger tiredness. The tiredness, in turn, affects productivity at work. If the loss of individuals, resulting from congestion, are summed, one can conclude that a city's economy is degraded by congestion.

This is a phenomenon that happens in Jakarta Metropolitan Area (hereafter called JMA), a region which is located in Java Island, Indonesia. This region is a metropolitan area consisting of several cities, including Jakarta (the capital city of Indonesia), Bogor, Depok, Tangerang, and Bekasi. Jakarta City itself is regarded as one of the most congested city in the world [4]. Severe congestion happens every day during workday resulting in high congestion, greenhouse gas emission and travel time loss. One of the main causes is the commuting activities of people from Bogor, Depok, Tangerang, and Bekasi to Jakarta, to carry out various activities including going to school and working.

The interesting part is that the Jakarta Local Government, as well as the Central government, has been making an effort to cope with this challenge. The public transport system has been gradually developed and will continue for several years ahead. This includes public transportation modes such as Bus Rapid Transit 
(BRT), Commuter Line, Mass Rapid Transit (MRT), Light Rapid Transit (LRT), etc. This study reviews the development of the transport system in the JMA, and propose a recommendation to enhance the development of a sustainable transportation system in Jakarta. There is numerous public transport mode that operates in Jakarta. This paper only focuses on major transport mode, namely Transjakarta BRT, KRL Commuter Line and Jakarta MRT. In addition, this paper also discusses transport mode, such as the City and Metropolitan LRT, are still under construction (has not started its operation) The data and information contained in this paper will be useful for future research concerning transportation system development in JMA.

\section{JMA Demographic and Socio-Economic}

JMA is a region located in Java Island, Indonesia. It consists of Jakarta City (the Capital City of Indonesia), Bogor City, Bogor District, Depok City, Tangerang City, Tangerang District, Bekasi City, and Bekasi District. JMA is the metropolitan area with the highest population, compared to other metropolitan areas in Indonesia. As explained by [5], JMA is the home to approximately 31 million people in 2015 and is estimated to reach around 50 million in the next 30 years. At the heart of JMA lies the capital city of Indonesia, namely Jakarta City. Jakarta City is, by far, the most developed city in Indonesia. This is reflected by its gross domestic product, at USD 147.817 billion in 2015 [6] or $17 \%$ share of Indonesia's total gross domestic product. A strikingly high economic density of Jakarta City, compared to other areas in Indonesia, is highlighted in [7], which is shown in Figure 1.

Jakarta City also has a high population as it is home to 10 million people. This number increases by 2.5 million due to the fact that people from peripheral cities commute to Jakarta during daylight to carry out various activities.

However, it is interesting to note that, according to [8], the population share of Jakarta City among other cities or district in Jakarta has decreased from $54.6 \%$ in 1990 to $35.5 \%$ in 2010 . This is an indication that people are moving further from Jakarta to its peripheral cities or districts. Moreover, this trend is confirmed with the population growth rate of Bogor, Depok, Tangerang, and Bekasi at 3\%. This growth rate is higher than the Jakarta City population growth rate, namely at $1.5 \%$ annually between 2000 and 2010. This is a phenomenon which is called urban sprawling, which is also indicated by the sprawling of built-up areas around the core of JMA [9] but still, the core itself, which is Jakarta City, stays the same. In other words, people live further away from the core of JMA but still travels every day to Jakarta City to carry out activities to fulfill their needs. This results in prolonged travel time and worsening traffic congestion, especially for people who use private mode of transport such as car and motorcycle.

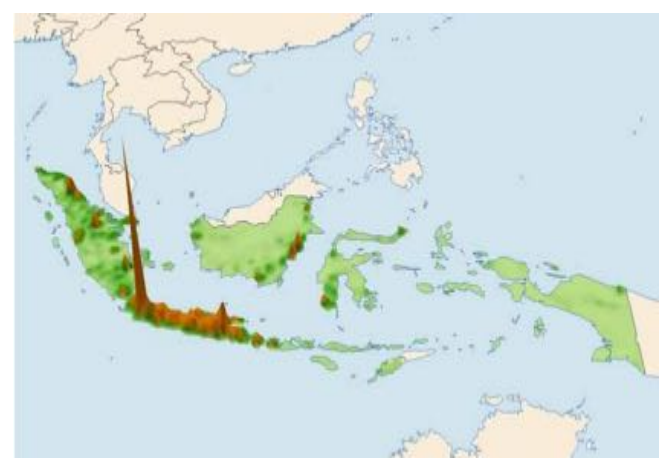

Figure 1 Economic density of regions in Indonesia [7]

\section{JMA Transportation Trend}

In line with its high population, JMA also has a high vehicle population, especially a private vehicle. This is shown by the data in [10] which stated that, from 2010 to 2016, the number of cars increased from approximately 2.3 million to 3.5 million while for motorcycle, the number increased from around 8.7 million to 13.3 million. The complete figure is shown in Figure 2. This significant increase is likely due to the fact that it is easy to own a vehicle, especially a motorcycle.

Everyday, numerous people (commuters) come from JMA peripheral cities or district comes to Jakarta to carry out various activities. This is shown by the data collected by [11] as shown in Figure 2. This makes Jakarta City, the core of JMA have to vary high vehicle population, especially during daytime when people carry out their activities.

In spite of that, the growth rate of road length in Jakarta is very low. The vehicle growth clearly outnumbers the growth of road length. This limited road capacity, if combined with high trip demand, will result in severe congestion. Unfortunately, this is the case for the core of JMA. The Greater Jakarta Transport Authority in [12] mentioned that the trip demand in Jakarta City reached 47.5 million trips/day and the majority of them are made by private transportation. This case is strengthened by [9], which stated that the modal share in Jakarta City is dominated by private transport, as shown in Figure 3. 


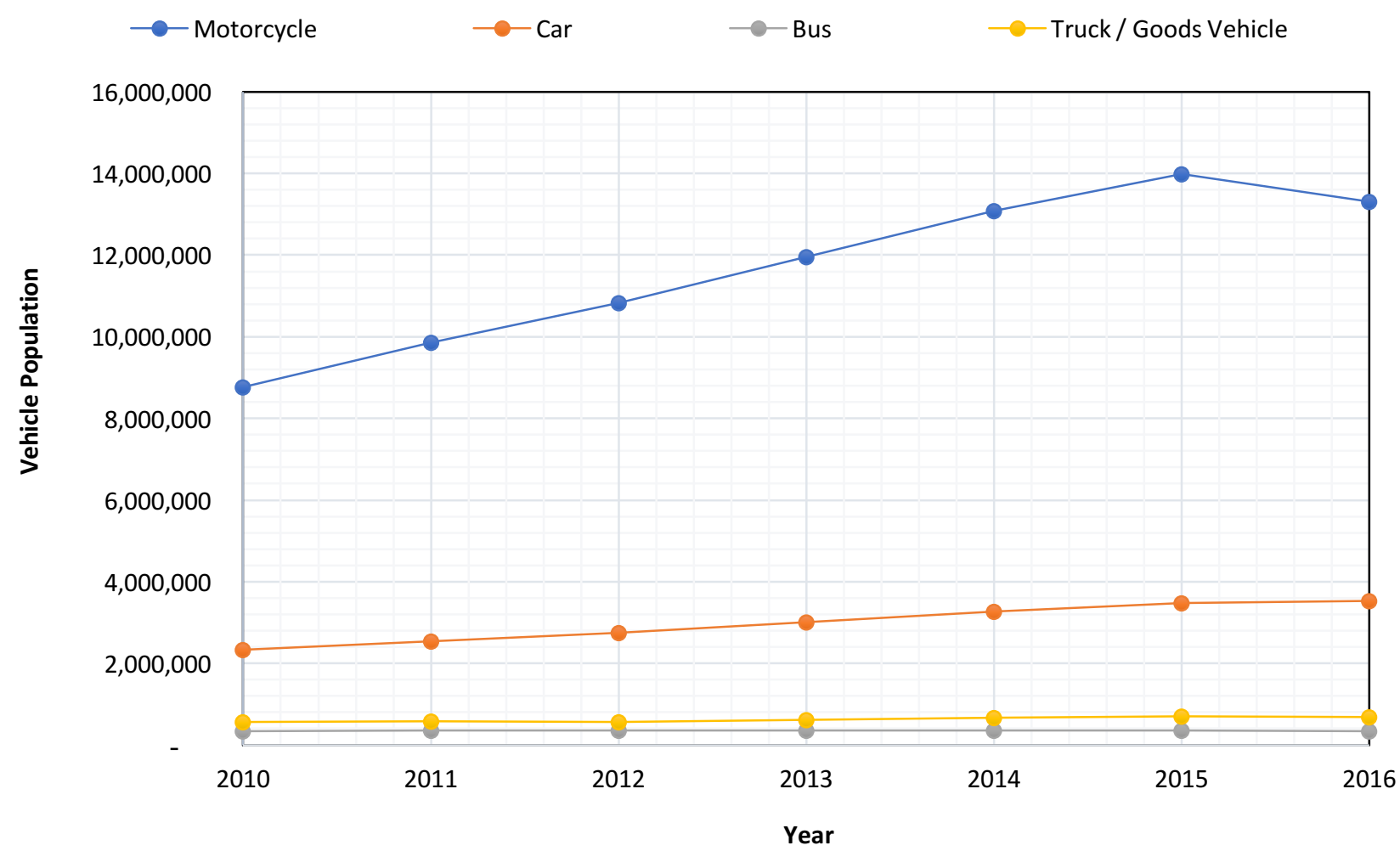

Figure 2 Number of registered vehicles at JMA [6]

Table 1 JMA commuter flow [11]

\begin{tabular}{lccccc}
\hline $\begin{array}{c}\text { Origin } \\
\text { (Settlement Location) }\end{array}$ & South Jakarta & East Jakarta & Central Jakarta & West Jakarta & North Jakarta \\
\hline South Jakarta & - & 49,003 & 99,594 & 39,739 & 20,733 \\
East Jakarta & 113,285 & - & 99,594 & 34,455 & 70,899 \\
Central Jakarta & 38,783 & 18,185 & - & 36,219 & 25,574 \\
West Jakarta & 56,321 & 9,671 & 98,557 & - & 88,936 \\
North Jakarta & 18,369 & 24,408 & 67,209 & 38,561 & - \\
Bogor District & 44,665 & 20,457 & 48,158 & 17,414 & 6,443 \\
Bogor City & 7,304 & 5,937 & 8,370 & 5,345 & 918 \\
Depok & 157,175 & 49,896 & 50,378 & 15,239 & 11,405 \\
Tangerang District & 7,764 & 2,505 & 11,990 & 15,717 & 4,846 \\
Tangerang City & 55,556 & 3,724 & 34,446 & 89,864 & 9,472 \\
South Tangerang City & 130,142 & 7,057 & 40,188 & 27,649 & 5,839 \\
Bekasi District & 3,359 & 63,126 & 20,431 & 7,869 & 22,117 \\
Bekasi City & 71,463 & 154,175 & 73,924 & 23,368 & 36,601 \\
\hline
\end{tabular}




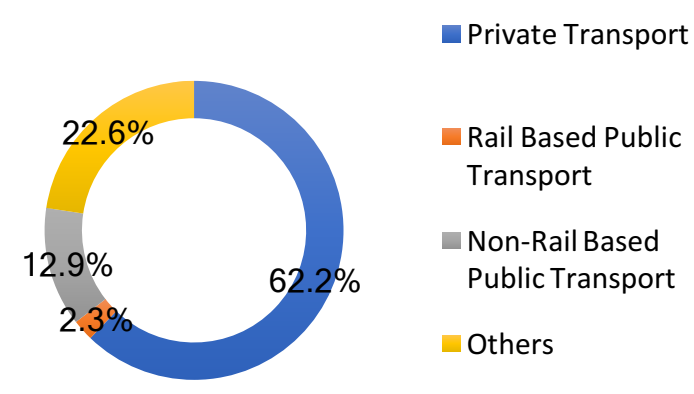

Figure 3 Trip model share in Jakarta city [9]

The combination of high travel demand, high modal share on private transportation and slow road expansion causes severe congestion in JMA, particularly at its core, Jakarta City. The data in [9] explains that the majority of the road segment in Jakarta City has a very low spot speed, especially during morning or evening peak hour, as shown in Figure 4 and Figure 5.

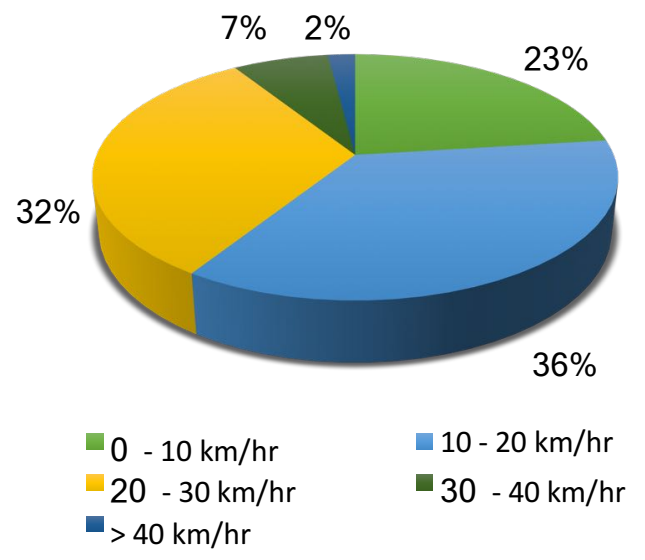

Figure 4 Jakarta city road segment spot speed during morning peak hour [9]

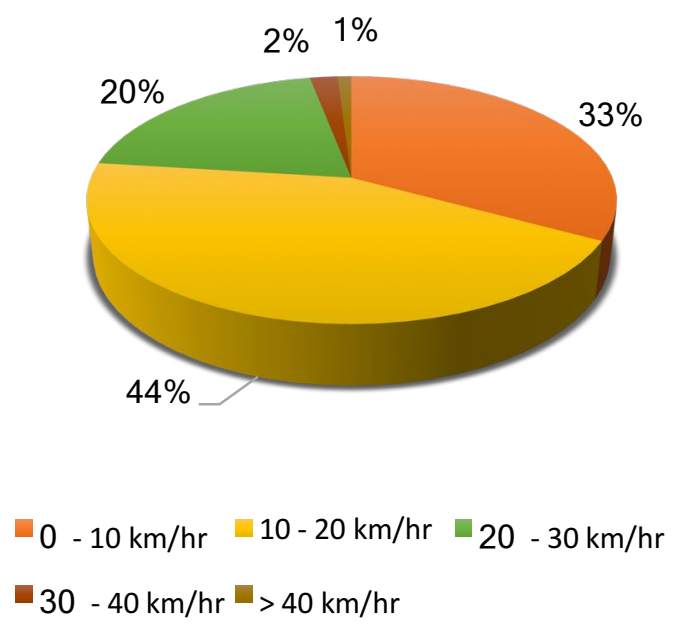

Figure 5 Jakarta city road segment spot speed during evening peak hour [9]
As a result of that, Jakarta City is experiencing substantial financial loss at IDR 25.2 trillion (USD 1.85 ) annually [13] and also a high amount of emission. To cope with this problem Jakarta Local Government, as well as Central Government, have been creating plans, implement policy and operating public transport mode to alleviate congestion in JMA. Several public transport infrastructures have been in operation in several years while the other will start operating in 2019 or 2020. Those public transport modes are highlighted below.

\section{$4 \quad$ Public Transport Infrastructure in Jakarta}

JMA currently has two main public transport mode that connects its core with its peripheral cities/district. Those modes are Transjakarta BRT and Metropolitan Commuter Line, which is a rail-based metro rail. However, in the near future, JMA will soon have other public transport modes such as the MRT and LRT.

\subsection{Transjakarta BRT}

JMA has a BRT system called Transjakarta. This BRT system started its operation in 2004, in spite of public resistance as, initially, the BRT system reduces road capacity for a private vehicle. At present, Transjakarta BRT is operated by Transportasi Jakarta Corp, an enterprise established by Jakarta Local Government. The Transjakarta bus runs in a dedicated lane, and the network connects various places in Jakarta City as well as the edge of JMA peripheral cities (Depok, Tangerang, and Bekasi). The system has the longest BRT lane, at $230.9 \mathrm{~km}$. Up until 2017, Transjakarta BRT has 1347 fleet, 228 shelters which are spread in 13 corridors [14]. The system also covers a wide area of Jakarta City, as shown in Figure 6.

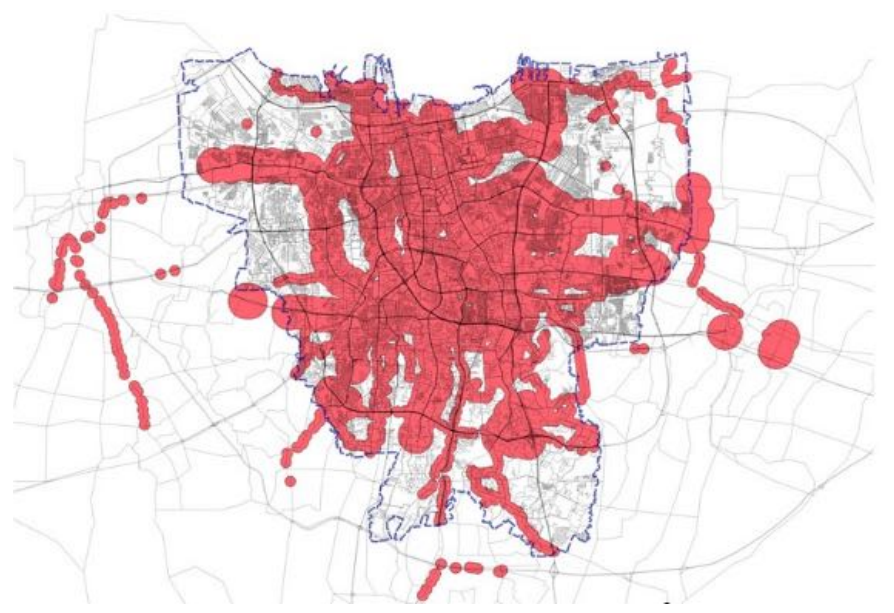

Figure 6 Transjakarta BRT coverage area $\left(280.5 \mathrm{~km}^{2}\right)$ year 2018 [15] 
Since the start its operation in 2004, the number of daily passengers has been increasing until 2014. However, the number of daily passengers dropped in 2015 and rose again in 2016. This may be the results of the addition of bus fleet and routes. Transjakarta BRT has also been gradually increasing its lane length. In 2004, the lane length was only $13.6 \mathrm{~km}$. In 2017 , the length has reached $230.9 \mathrm{~km}$ [14]. The change in Transjakarta daily passenger and also lane length is shown in Figure 7.

\subsection{KRL commuter line}

A wide area of JMA is connected by commuter rail, which is called the KRL commuter line. The commuter line is a transport mode that has been in operation since 1924. At that time, the commuter line was operated by a Dutch colonial railway company. The operation was taken over, after Indonesia's Independence in 1945, by the Indonesian Railway Bureau. In 2008, Indonesia
Railway Corp., a state-owned company whose role is to operate the railway system in Indonesia, formed a subsidiary company to manage the commuter line named KAI Commuter Jabodetabek Corp. Starting from 2017, the subsidiary company changed its name to PT Kereta Commuter Indonesia (KRL Commuter Line Indonesia Corp) [16].

The commuter line network covers Jakarta City as well as its peripheral cities. Moreover, the line also reaches Rangkasbitung, a district located in Banten province. The trip coverage for the commuter line reaches $385 \mathrm{~km}$ [17]. The map of the commuter line route is shown in Figure 8.

The commuter line system has 79 stations and 760 fleets. To ease the passenger to buy a ticket on the station, the commuter line system also has 164 vending machines that can be found in all of its stations [18].

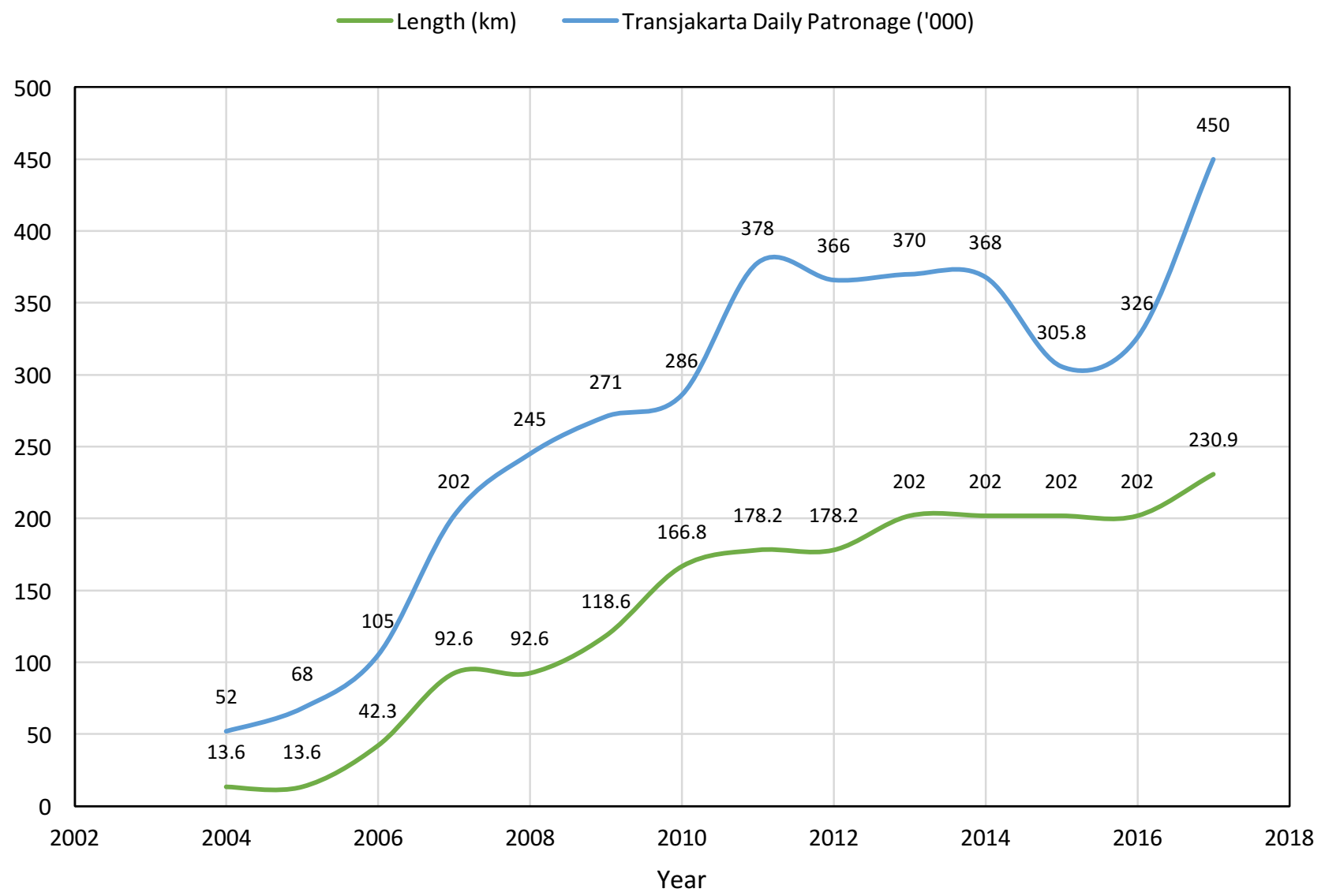

Figure 7 Transjakarta BRT lane length and daily ridership [12, 14, 19] 


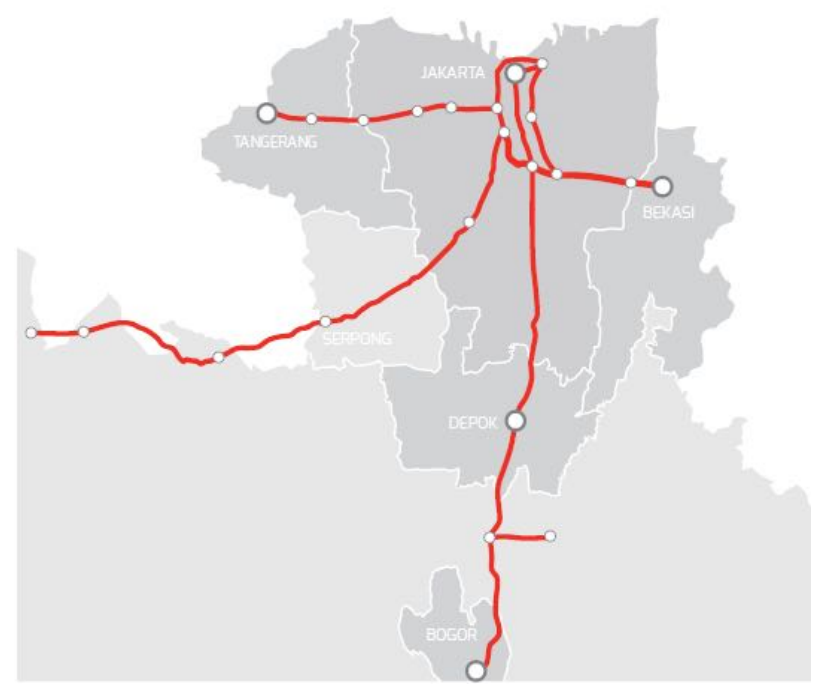

Figure 8 Jakarta commuter line network [20]

The presence of the commuter allows large movement of people around JMA. The number of daily passengers has been increasing and reached an average of 993,804 passenger/day in 2017. On the same year, the commuter line reached its daily passenger peak at 1.065.522. The increase of KRL commuter line passenger year by year can be seen in Figure 9.

\subsection{MRT}

The Jakarta city government has started operating its new rail transport mode called Jakarta MRT. The plan to operate Jakarta MRT has actually been in existence since 1985. However, the plan was suspended and continued again in 2005. As a step forward to operate a MRT System in Jakarta, in 2008, Jakarta Local Government established Jakarta MRT Corp, which obligation is to construct and operate the Jakarta MRT System [21].

Up until now, the development of Jakarta MRT is divided into two phases. The $1^{\text {st }}$ phase track spans from Lebak Bulus to Bundaran HI area, while the $2^{\text {nd }}$ phase will start from Bundaran HI to Kampung Bandan Area. The picture of Jakarta MRT development phase can be seen in Figure 10. The $1^{\text {st }}$ phase started its operation in March 2019 [21].

Per March 2019, Jakarta MRT has 16 train set with six cars per train set and operates from 5 AM to 12 AM in midnight. During rush hour, the headway of Jakarta MRT is 5 minutes [21].

\section{Commuter Line Daily Ridership}

$1,200,000$

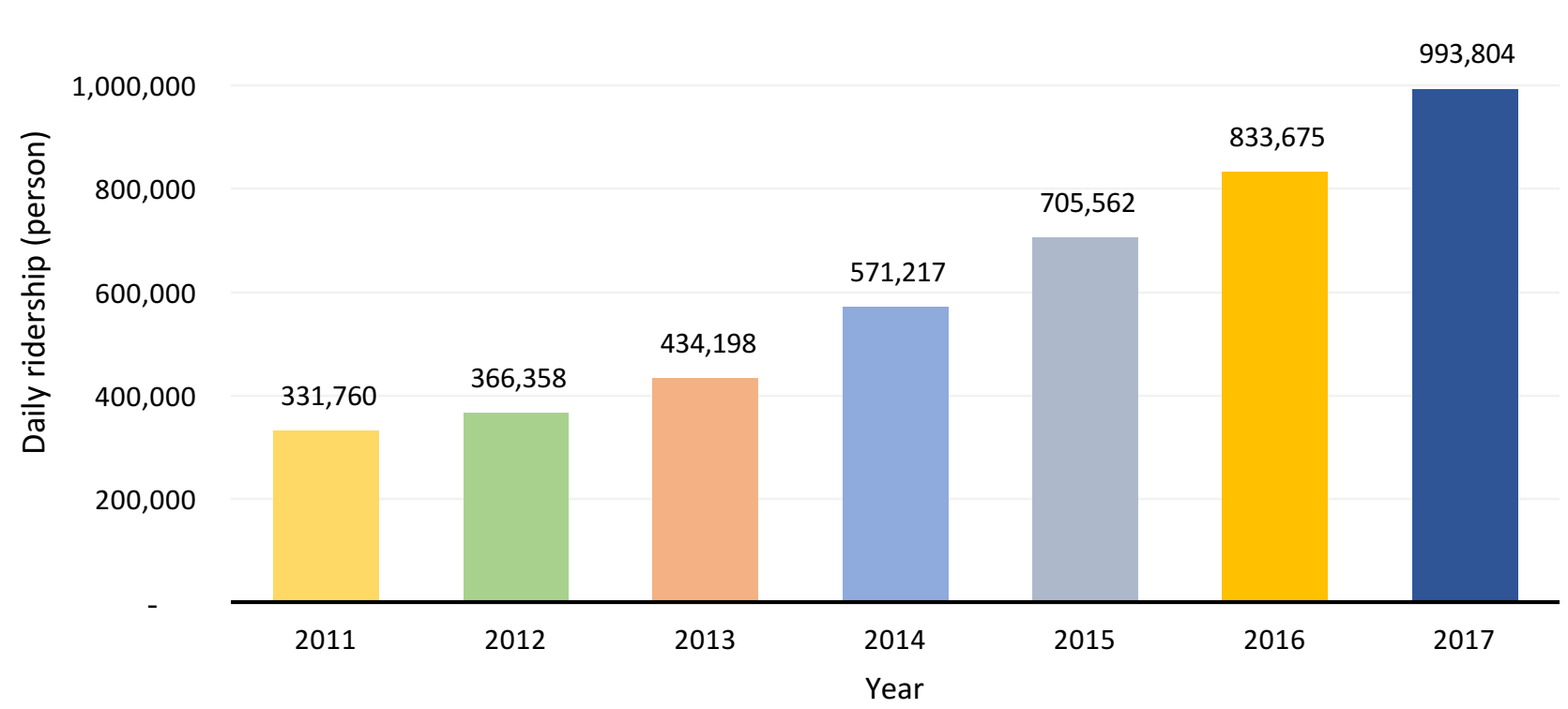

Figure 9 KRL commuter line average daily passenger [18, 20, 22] 


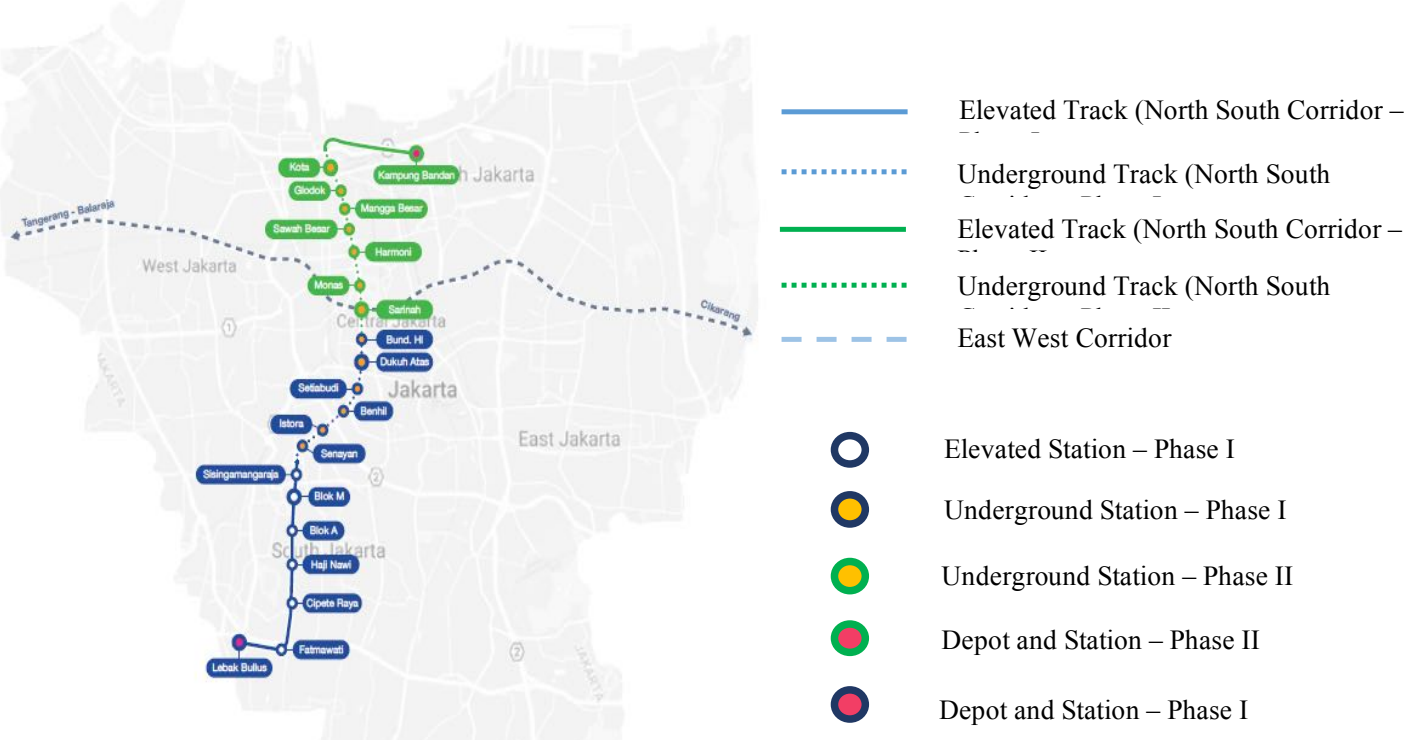

Figure 10 Jakarta MRT line (existing and planned) [23]

\subsection{LRT - Jabodetabek}

The other rail-based transport mode that will operate in JMA is the Jabodebek LRT. Jabodebek is an acronym from JMA cities that are connected by the LRT, namely Jakarta, Bogor, Depok, and Bekasi. The basis of the LRT development is the Republic Indonesia Presidential Regulation number 98 the year 2015 regarding the acceleration of LRT development in Jakarta, Bogor, Depok, and Bekasi. The LRT infrastructure is now under construction and is planned to operate by the end of 2019. The LRT network will

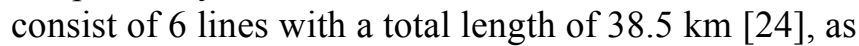
described in the following:
a. Cawang-Cibubur Line
b. Cawang - Kuningan - Dukuh Atas Line
c. Cawang - East Bekasi
d. Dukuh Atas - Palmerah - Senayan Line
e. Cibubur - Bogor Line
f. Palmerah - Grogol Line

The network map of Jabodebek LRT is shown in Figure 11. After the construction phase has finished, the Jabodebek LRT will be operated by Indonesia Railway Corp (PT. KAI).

\subsection{LRT - Jakarta city}

Within the city in Jakarta, a city LRT mode will also operate. The construction and operation of this innercity LRT is based on Jakarta Act Number 1859, year 2015 regarding LRT line. According to the government act, the LRT will consist of 7 lines, as follows: a. Line 1: Kebayoran Lama - Kelapa Gading (length: $21.6 \mathrm{~km})$

b. Line 2: Tanah Abang - Pulo Mas (length: $17.6 \mathrm{~km}$ )

c. Line 3: Joglo - Tanah Abang (length: $11.5 \mathrm{~km}$ )

d. Line 4: Puri Kembangan - Tanah Abang (length: $9.3 \mathrm{~km})$

e. Line 5: Pesing - Kelapa Gading (length: $20.7 \mathrm{~km}$ )

f. Line 6: Extension Kemayoran - Ancol (length: 5 $\mathrm{km})$

g. Line 7: Bandara Soeta - PIK - Pluit - Ancol Kemayoran - Cempaka Putih (length: 30.5 km)

The first line that will operate is the one that will connect Velodrome station and Pegangsaan Dua station (Kelapa Gading). The length of the line between the two stations is approximately $5.8 \mathrm{~km}$.

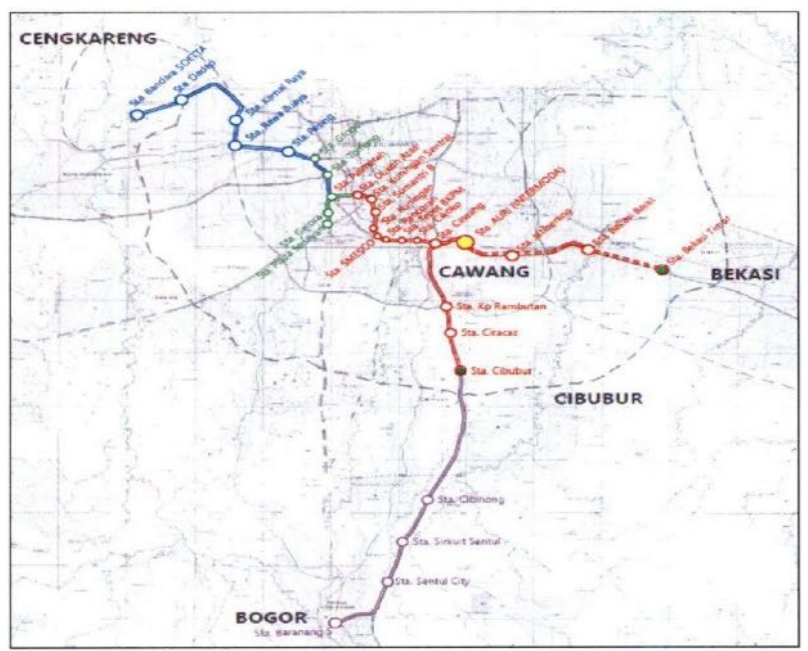

Figure 11 Jabodetabek LRT network [25] 


\subsection{Transit oriented development}

The [26] is also partnering with Jakarta MRT Corp. to develop Transit Oriented Development (TOD) area in Dukuh Atas. This point is currently the interchange between 4 different transportation modes, namely Transjakarta BRT, Jakarta MRT, KRL Commuter Line and Soekarno-Hatta Int. Airport Railway Link. In the future, one transport mode that will be connected with the Metropolitan (Jabodebek) LRT, which is now still under construction.

There are, however, several challenges to integrate different public transport mode in the Dukuh Atas Transit Development Area. Those challenges are outlined by the [26]. Broadly speaking, the challenges are related to different transport mode operator and multiple stakeholders. This pose challenges in terms of program coordination and synchronization. [26] further stated that there has to be a solution that overcomes the challenges. Those solutions include various aspects, such as regulatory, institutional, funding scheme and asset management.

\section{Conclusion and Recommendation}

JMA has been experiencing worsening congestion, as a result of its high economic output, high population, high demand movement but limited road length/capacity and inadequate public transport capacity. Such condition contributes to the condition that is already unfavorable, namely high time value loss, high fossil fuel consumption, high greenhouse gas emission that creates global warming as well as lung disease.

This issue has gained the attention of both the government and public as almost all commuters in the JMA has perceived the bad impact caused by congestion. Both the central and city government are now making effort to solve congestion problem by improving the service of the existing public transport (Transjakarta BRT and KRL Commuter Line) as well as constructing and operating new transportation mode (The Jakarta MRT, City and Metropolitan LRT). This is a major step taken by the government to create a city and a metropolitan area that is connected by public transportation. The public transport network mentioned above, if combined, will be able to reach most of important places in Jakarta as the core of JMA.

However, several points should be noted to optimize the benefit of those public transport mode to society. There are three components that are required to achieve sustainable transport development. Those components are i) strong transport authority, ii) integrated master plan, iii) sustainable resources, funding, and finance (attracting private capitals/PPPs).

\section{i) Strong transport authority}

The presence of a Metropolitan Transport Organization (MTO) is required to create a master plan for integrated public transport development and to make a decision on public transport affair in a metropolitan area. Metropolitan public transport affair usually encompasses several cities and goes beyond administrative boundaries. It will be a disadvantage if the planning and development of public transport it is decided partially by different authorities / local government within the metropolitan area. The role of transport authority, therefore, is to coordinate transport system development among different authorities, and, at a more advanced level, become an institution that has strong authority for transport development that is followed/referred by different authorities.

ii) Integrated master plan

To achieve sustainable and integrated public transportation system, the existence of a transportation master plan for the JMA is highly necessary. The plan to integrated different transport mode and infrastructure as well as the land use (Transit Oriented Development) around public transport corridor should be laid out on the Master plan. Moreover, the masterplan should set the standard for the quality of public transport service. This encompasses convenience, equity, accessibility, safety, security, and reliability.

iii) Sustainable resources, funding, and financing (attracting private capitals / PPPs)

To operate sustainably, public transportation system requires sufficient funding, technical expertise, and professionals. With respect to funding, public transport can gain more revenue from its passenger (fare-box ratio) by continuously improving the service. However, in many cases around the world, revenue from passenger alone is not enough to finance public transport operation. Even though public funding is available, though limited, to subsidize public transport, possible opportunities for funding source should be identified and utilized. Public-private partnership scheme is one option that can be utilized by partnering with the private sector to build/operate public transport. In addition to that, value capture schemes such as property management, advertisement, etc. are several measures that can be considered to finance a public transport system.

With respect to supporting policies, the development of public transport should be accompanied by strong demand management measures, i.e. parking control, electronic road pricing, etc. as well as other urban pricing control instruments. This is to note that JMA has a very high travel demand thus making the 
implementation of demand management measure necessary.

With those components being put in place, as well as strong demand management policies, the JMA will be closer towards achieving a sustainable transport system.

\section{Acknowledgment}

The making of this paper is supported by The Korea Transport Institute (KOTI) through Regional Transport Research 2017 program and also partially funded by the United States Agency for International Development (USAID) through Sustainable Higher Education Research Alliances (SHERA) program.

\section{References}

[1] D. Banister, Transport Policy and the Environment. London: E \& FN Spon, 1998.

[2] P. Moriarty and D. Honnery, "Global Transport Energy Consumption," in Alternative Energy and Shale Gas Encyclopedia, Hoboken, NJ, USA: John Wiley \& Sons, Inc., 2016.

[3] O. Publishing and I. E. Agency, CO2 Emissions from Fuel Combustion 2005. Organisation for Economic Cooperation and Development, 2005.

[4] "TomTom Traffic Index.".

[5] J. S. Younger et al., "Greater Jakarta, the world's second largest conurbation - part 1," Proc. Inst. Civ. Eng. - Munic. Eng., vol. 168, no. 4, pp. 253-261, Dec. 2015.

[6] Jakarta Central Bureau of Statistics, Jakarta in Figures. Jakarta Central Bureau of Statistics, 2016.

[7] W. Bank, World Development Report 2009. The World Bank, 2008.
[8] T. Firman and F. Z. Fahmi, "The Privatization of Metropolitan Jakarta's (Jabodetabek) Urban Fringes: The Early Stages of 'Post-Suburbanization' in Indonesia," $J$. Am. Plan. Assoc., vol. 83, no. 1, pp. 68-79, Jan. 2017.

[9] Ministry of Transportation, "Jakarta Metropolitan Area Transport Master plan," 2015.

[10] Jakarta Central Bureau of Statistics, Jakarta Transport Statistics. Jakarta Central Bureau of Statistics, 2016.

[11] Central Bureau of Statistics, Jakarta Metropolitan Area Commuter Statistics. Central Bureau of Statistics, 2014.

[12] E. Sinaga, "Jakarta Metropolitan Area Public Transport System Integration Facilities," 2017.

[13] Indonesia Habitat National Team, "Indonesia National Report For Habitat III," 2016.

[14] PT Transportasi Jakarta, "PT Transportasi Jakarta," 2017. .

[15] PT Transportasi Jakarta, "Transjakarta Coverage Area," 2018. .

[16] Commuterline Indonesia, "KRL - Commuterline Indonesia," 2018. .

[17] Commuterline Indonesia, “Annual Report 2016,” 2016.

[18] Commuterline Indonesia, “Annual Report 2017," 2017.

[19] P. Sayeg, "Post evaluation of a decade of experience with Jakarta's Transjakarta Bus Rapid Transit System," in Australasian Transport Research Forum 2015 Proceedings, 2015.

[20] Commuterline Indonesia, “Annual Report 2015,” 2015.

[21] Jakarta MRT Corp., "MRT Jakarta - Jakarta Metro Mass Rapid Transit.".

[22] N. Fadhila, "Challenges and Obstacles in Urban Commuter Line Development," 2017.

[23] Jakarta MRT Corp., “Annual Report 2016,” Jakarta, 2016.

[24] B. Hartono, "Integrated Light Rapid Transit in Jakarta, Bogor, Depok and Bekasi Area," 2017.

[25] Republic of Indonesia Presidential Office, Light Rapid Transit Development Acceleration for Jakarta, Bogor, Depok and Bekasi Area. 2015.

[26] Greater Jakarta Transport Authority, "Jakarta Metropolitan Area Transport Integration Program,” Jakarta, 2017. 